\title{
PREDATION OF FELIS CATUS (LINNAEUS, 1758) BY BOA CONSTRICTOR AMARALI (STULL, 1932) \\ PREDAÇ̃̃O DE FELIS CATUS (LINNAEUS, 1758) POR BOA CONSTRICTOR AMARALI(STULL, 1932)
}

\author{
MARCos TOKUdA $^{1^{*}}$ \&ANDrÉ Luiz Mota DA Costa ${ }^{1}$ \\ ${ }^{1}$ Parque Zoológico Municipal Quinzinho de Barros, Sorocaba, São Paulo, Brazil. \\ Correspondence:marcostokuda@gmail.com \\ Received: 2020-12-09. Accepted: 2021-04-27.
}

Resumo.- A maioria dos mamíferos predados por Boa constrictor são primatas médios e pequenos, roedores, gambás e morcegos. Em geral, mamíferos predadores não fazem parte da dieta de B. constrictor. Nessa nota, relatamos a predação de Felis catus por Boa constrictor amarali. Relatos de eventos anedóticos como este são importantes para enfatizar o hábito alimentar oportunista e generalista de B. constrictor e sua capacidade de viver em áreas antropogenizadas.

Palavras chave.- Alimentação, jiboia-do-cerrado, boidae, gato doméstico, plasticidade comportamental.

Abstract.- The most predated mammals by Boa constrictor are median and small primates, rodents, opossums and bats. In general, predatory mammals are not part of the diet of B. constrictor. Here we report the predation of Felis catus by Boa constrictor amarali. Reports of anecdotal events like this are important to emphasize the opportunistic and generalist feeding habit of $B$. constrictor and their ability to live in an anthropogenic landscape.

Keywords.- Feeding, Amaral's Boa, boidae, domestic cat, behavioral plasticity.

Several studies showed that Boa constrictor is a generalist predator, feeding on mammals, birds and lizards (Martins \& Oliveira, 1998; Quick et al., 2005). The most predated mammals by $B$. constrictor are median and small primates, rodents, opossums, and bats (Bakkergard \& Timm, 2001; Pizzatto et al., 2009; Quintino and Bicca-Marques, 2013). In general, predatory mammals are not part of the diet of $B$. constrictor, and to our knowledge there are only two reports in literature of felids being preyed by B. constrictor, a Puma yagouaroundi (Monroy-Vilchis et al., 2011) and a Felis catus (Martinelli et al., 2011).

Here we report a new record of predation of Felis catus by Boa constrictor amarali. On 18 February 2019, an adult female of $B$. constrictor amarali (snout-vent length $=181 \mathrm{~cm}$; tail length $=18 \mathrm{~cm}$; $7.9 \mathrm{~kg}$ ) was found in an area by a landfill in the municipality of Iperó (-23.427574, -47.549954), São Paulo State, Brazil. The landfill is surrounded by pasture and small forest fragments, and nearby there is a road $(0.5 \mathrm{~km})$ and a neighborhood (approximately 1.5 $\mathrm{km})$.

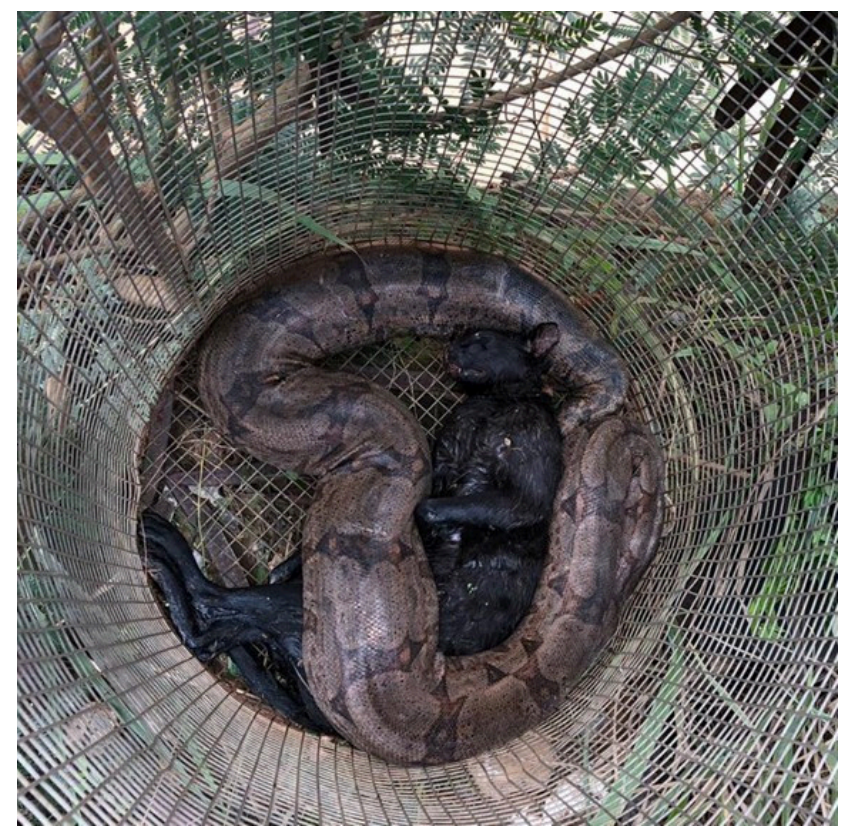

Figura 1. Fêmea adulta de B. constrictor amarali e gato doméstico adulto que foi regurgitado. Foto: Ivo da Silva.

Figure 1. Adult female B. constrictor amarali and adult domestic cat that was regurgitated. Photo: Ivo da Silva. 
The specimen was captured by the Fire Department, and few minutes later the snake regurgitated an adult domestic cat (Felis catus; Fig. 1). The snake was brought to the Parque Zoológico Municipal Quinzinho de Barros (PZMQB), in the municipality of Sorocaba, São Paulo State. The PZMQB, known as Sorocaba Zoo, was founded in 1968 and is a government agency. After veterinary clinical examination, B. constrictor amarali was released in a forest reserve.

Anthropogenic environments can provide novel opportunities to predators to feed upon preys that would not normally be in their natural diet (Fleming \& Bateman, 2018). Reports of anecdotal events like this are important to emphasize the opportunistic and generalist feeding habit of B. constrictor, as well as their ability to live in anthropogenic landscapes. In addition, domestic cats have been documented preying upon a wide range of animal species, reducing or even extirpating native populations (Burbidge \& Manly, 2002). Thus, protecting the predators of feral populations of Felis catus may be beneficial to ecosystem.

Acknowledgements.- We would like to thank the Secretaria de Meio Ambiente e Sustentabilidade de Sorocaba for the support.

\section{CITED LITERATURE}

Bakkegard, K.A. \& R.M.Timm. 2001. Boa constrictor (Boa constrictor): Diet. Herpetological Review 32:261-262.
Burbidge, A.A. \& B.F. Manly. 2002. Mammal extinctions on Australian islands: causes and conservation implications. Journal of biogeography 29:465-473.

Fleming, P. A., \& P.W. Bateman. 2018. Novel predation opportunities in anthropogenic landscapes. Animal Behaviour 138:145-155.

Martinelli, M.M., T.A.Volpi \& A.V. Matos. 2011. Boa constrictor (Boa constrictor). DIET. Herpetological Review 42:97.

Martins, M. \& M.E. Oliveira. 1998. Natural history of snakes in forests of the Manaus region, Central Amazonia, Brazil. Herpetological Natural History 6:78-150.

Monroy-Vilchis, O., Ó. Sánchez \& V. Urios. 2011. Consumo de un jaguarundi adulto Puma yagouaroundi (Felidae) por la serpiente Boa constrictor (Boidae) en el centro de México. Revista mexicana de biodiversidade 82:319-321.

Pizzatto, L., O. Marques \& K. Facure. 2009. Food habits of Brazilian boid snakes: overview and new data, with special reference to Corallus hortulanus. Amphibia-Reptilia 30:533-544.

Quick, J.S., H.K. Reinert, R. Eric \& R.A. Odum. 2005. Recent occurrence and dietary habits of Boa constrictor on Aruba, Dutch West Indies. Journal of Herpetology 39:304-307.

Quintino, E.P. \& J.C. Bicca-Marques. 2013. Predation of Alouatta puruensis by Boa constrictor. Primates 54:325-330. 